\title{
CENSURA $^{1}$
}

\author{
CENSORSHIP
}

Sandra Regina Carvalho Martins*

\begin{abstract}
Resumo:
A censura deve ser entendida como a ação governamental, de ordem prévia, sobre o conteúdo de uma mensagem, realizada por funcionário público denominado censor. Após a Constituição da República Federativa do Brasil de 1988, a censura é caracterizada como um verdadeiro ilícito constitucional, sendo ato injusto, arbitrário e discriminatório. Porém, nem sempre foi assim, o que pode ser verificado no breve histórico das Constituições e legislações brasileiras a partir de 1824. Importante ressaltar que a liberdade de expressão e o direito à vida privada, à intimidade, ao segredo e à imagem devem ser sopesados no caso concreto, não cabendo aludir-se à censura nestes casos.

Palavras-chave: Censura. Ilícito Constitucional. Liberdade de Expressão. Direitos da Personalidade. Direito de Autor.
\end{abstract}

\begin{abstract}
:
Censorship should be understood as government action, of previous order, about the content of a message, carried out by the public servant called Censor. Since the Constitution of the 1988 Federative Republic of Brazil, censorship has characterized as a true constitutional offense, an unfair, arbitrary and discriminatory act. But it was not always so, as may be seen in a brief history of the Constitutions and Brazilian legislation from 1824. It's important to note that freedom of expression and the rights to privacy, intimacy, secrecy and image should be balanced in each case, without possibility for any allusion to censorship in these cases.
\end{abstract}

Keywords: Censorship. Constitutional Violation. Freedom of Expression. Personality Rights. Copyrights.

\section{Introdução}

O que é censura? De acordo com o Novo Dicionário da Língua Portuguesa Aurélio Buarque de Holanda Ferreira (1975, p. 305) é o exame de qualquer texto de caráter

\footnotetext{
Texto originalmente apresentado como requisito parcial para aprovação na disciplina DCV5926-1 - Direitos Intelectuais. Direito de Autor no Terceiro Milênio: Do Mecenato às novas Tecnologias na Sociedade da Informação, do Departamento de Direito Civil da Faculdade de Direito da Universidade de São Paulo, sob a regência da Professora Titular Silmara Juny de Abreu Chinellato e do Professor Doutor Antonio Carlos Morato, em junho de 2016.

* Doutoranda em Direito Civil pela Faculdade de Direito da Universidade de São Paulo - USP, sob a orientação do Professor Titular Álvaro Villaça Azevedo. Mestre em Direito Civil pela Faculdade de Direito da Universidade de São Paulo - USP. Especialista em Direito de Família e Sucessões pela Escola Superior de Advocacia de São Paulo (ESA/SP). E-mail: sanrcm2012@usp.br.
} 
artístico ou informativo, feito pelo censor a fim de autorizar sua publicação, exibição ou divulgação. É também condenação, reprovação, crítica.

Por outro lado, neste mesmo dicionário (1975, p. 305), censor é o funcionário público encarregado da revisão e censura de obras literárias ou artísticas, ou da censura aos meios de comunicação de massa: jornais, rádio, etc.

O texto acima, do Dicionário Aurélio, datado de 1975, deixa ver claramente, pela própria definição dos termos, a existência da censura estatal, devidamente regulamentada e realizada por funcionário público denominado censor.

Em edição de 2010 do mesmo Dicionário Aurélio (2010, p. 154), o significado já não é mais o mesmo, pois se trata de exame crítico de obras literárias ou artísticas, e também de crítica, e repreensão.

Porém em ambos restaram os significados de crítica, reprovação.

Conforme o Vocabulário Jurídico, de De Plácido e Silva (1998, p. 163), censura é também pena disciplinar, compreendida na repressão oficial passada por uma autoridade, hierarquicamente superior, ao funcionário de categoria inferior e sob suas ordens, em virtude de falta ou omissão cometida no exercício de seu cargo ou de funções. No mesmo sentido de pena também é aplicada pelo Direito Canônico. E, assim, diz-se censura eclesiástica à pena espiritual imposta ao fiel, que transgrediu preceito da religião.

Crítica, reprovação, pena, certo é que a censura estatal não pode mais existir em nossos dias, como veremos adiante.

O que diz a Constituição da República Federativa do Brasil sobre censura? Na ordem instituída pela Constituição de 1988, contemplam-se diversos dispositivos, todos de dicção claríssima: art. 5 IV - é livre a manifestação de pensamento, sendo vedado o anonimato; IX - é livre a expressão da atividade intelectual, artística, científica e de comunicação, independentemente de censura ou licença; art. 220: A manifestação do pensamento, a criação, a expressão e a informação, sob qualquer forma, processo ou veículo não sofrerão qualquer restrição, observado o disposto nesta Constituição; § $1^{\circ}$ Nenhuma lei conterá dispositivo que possa constituir embaraço à plena liberdade de informação jornalística em qualquer veículo de comunicação social, observado o disposto no art. $5^{\circ}, I V, V, X, X I I I$ e XIV; $\S 2^{\circ}$ É vedada toda e qualquer censura de natureza política, ideológica e artística.

Portanto, hoje, a censura é caracterizada como um verdadeiro ilícito constitucional, sendo ato inerentemente injusto, arbitrário e discriminatório.

A censura significa ação governamental, de ordem prévia, centrada sobre o conteúdo de uma mensagem. Portanto, proibir a censura tem o significado de impedir que as ideias e fatos que o indivíduo pretende divulgar tenham que passar, antes, pela aprovação de um agente estatal (BRANCO, 2015, p. 265). 
Para melhor compreensão de tais definições acima, aparentemente contraditórias, passemos ao histórico da censura no Brasil. Assim, coletamos um conjunto de acontecimentos e legislações que mostram a história da repressão à liberdade do pensamento e da expressão no Brasil. O objetivo não é a perpetuação de ódios às gerações envolvidas no obscurantismo da repressão, mas de trazer tal história a fim de se evitar a repetição de tão desastrosos acontecimentos.

\section{Histórico da Censura no Brasil}

\subsection{Constituição de 1824}

Ensina Ana Luíza Martins (2002, p. 159-160) que a obra de conquista de novas terras pelo Reino português não foi uma ação isolada do Estado, pois, ela só foi possível pelo apoio efetivo da Igreja católica, que financiou parte dessa conquista, e tornou-se copartícipe do empreendimento, dividindo legalmente o poder com o Estado. Assim, o Estado-português era a Igreja católica e vice-versa. Verifica-se, então, a força com que a tradição católica chegou e atuou no Brasil, sendo que o Estado laico praticamente não existia. Eram da alçada da Igreja os registros de nascimentos, os cartórios de paz, a legislação urbana, a legalização dos casamentos e a educação. A censura não era só de livros, mas também sobre práticas, usos e costumes que contrariassem os prescritos pela Metrópole associada à Igreja.

A história das nossas constituições tem início com a Independência. A Constituição de 1824, outorgada por D. Pedro I, foi a mais longeva das constituições brasileiras, tendo durado 65 anos, e emendada apenas uma vez em 1834. Instituiu a monarquia constitucional e o Estado unitário. Estatuía o Poder Moderador, delegado privativamente ao Imperador, como Chefe Supremo da Nação. A ele incumbia nomear os senadores, dissolver a Câmara dos deputados, nomear e demitir ministro de Estado e, ainda, suspender juízes, por queixas feitas contra eles (BRANCO, 2015, p. 99).

$\mathrm{O}$ art. 179 da Constituição de 1824, em seu inciso IV, assegurava que:

Todos podem communicar os seus pensamentos, por palavras, escriptos, e publical-os pela Imprensa, sem dependencia de censura; com tanto que hajam de responder pelos abusos, que commetterem no exercicio deste Direito, nos casos, e pela fórma, que a Lei determinar. (Transcrição ipsis litteris). (CAMPANHOLE; CAMPANHOLE, 1976, p. 542).

Entende Luís Roberto Barroso (2001, p. 130) que "a Constituição de 1824 previa a liberdade de expressão, sem dependência de censura, ficção análoga à do princípio da igualdade perante a lei (art. 179, XIII), que conviveu com os privilégios da nobreza, o voto censitário e o regime escravocrata". 
A Lei de 11 de agosto de 1827 criou dois cursos jurídicos, um em São Paulo, a nossa Faculdade de Direito do Largo de São Francisco e outro em Olinda. Em seu art. $7^{\circ}$ assegurava que:

Os Lentes farão a escolha dos compendios da sua profissão, ou os arranjarão, não existindo já feitos, com tanto que as doutrinas estejam de accôrdo com o systema jurado pela nação. Estes compendios, depois de approvados pela Congregação, servirão interinamente; submettendo-se porém á approvação da Assembléa Geral, e o Governo os fará imprimir e fornecer ás escolas, competindo aos seus autores o privilegio exclusivo da obra, por dez annos. (Transcrição ipsis litteris). (COLLEÇÃO DAS LEIS. IMPÉRIO DO BRASIL, 1827).

Da leitura do art. $7^{\circ}$ da Lei de 11 de agosto de 1827 , poderíamos indagar se os professores tinham plena liberdade de criar os conteúdos de suas aulas, ou estariam sob vigilância ou censura?

Com fundamento no comentário do professor Luís Roberto Barroso e tendo em vista que as doutrinas deveriam estar de acordo com o sistema jurado pela nação e ainda que tais compêndios deveriam ser aprovados pela Congregação e pela Assembleia Geral, parece-nos que os Lentes não teriam total liberdade para discorrer sobre quaisquer assuntos, estando sim sob vigilância ou censura.

A despeito da severa censura, as obras iluministas entraram no Brasil. Aliás, as obras proibidas sempre entraram na Colônia por estratégias múltiplas. A atmosfera de culpa e medo que marcara a Colônia se mantém, em parte, no Império. A mudança fundamental não se dera. Em lugar da república laica almejada pela facção oposicionista às vésperas da Independência, vingara a monarquia católica, cujo modelo praticamente não diferia daquele colonial. Novamente, Igreja e Estado compartilhavam o poder, embora as figuras centralizadoras de D. Pedro I e mais tarde D. Pedro II se projetassem mais do que aquele da liturgia da Igreja. No entanto, um comércio paralelo de livros proibidos, atuou no Rio de Janeiro do Brasil recém-independente. (MARTINS, 2002, p. 166).

Mas, aos poucos, duas atenuantes foram favoráveis ao objeto-livro: a emergência e a propagação da literatura romântica, disseminando outra forma de leitura associada à atividade inofensiva, sobretudo afeta a mulheres; e o temperamento "ilustrado" do monarca D. Pedro II, leitor voraz, sempre em busca das últimas publicações do mercado. Assim, o poder oficial se retraía, uma vez que não se instituíra a censura oficial e os livros de interesse da elite ainda chegavam pelas mesmas vias indiretas, sob as vistas grossas de censores, sem registros de ostensiva apreensão. (MARTINS, 2002, p. 166-170).

Quanto à Igreja, esta ainda funcionava como a guardiã temida, controladora de pensamentos, palavras e ações. No entanto, “duas” Igrejas atuavam durante o Império, 
uma obstruindo e outra libertando as mentes. Aos padres influenciados pelo ideário liberal agregaram os bacharéis formados nas duas únicas escolas de Direito do país: a Academia de Direito do Largo de São Francisco, em São Paulo, e a Academia de Direito em Olinda, no Recife. Eram questionados os entraves que a Igreja católica impunha ao país, controlando suas instâncias fundamentais: a educação, a legislação, o espaço urbano, regendo os casamentos e enterrando os mortos. Assim, a luta dos liberais, sobretudo da maçonaria, voltou-se contra a Igreja. (MARTINS, 2002, p. 169-170).

Nos últimos anos do Império, não se pode afirmar que a censura incidiu exatamente sobre a circulação de ideias, mas sim sobre os núcleos fomentadores de sua prática. Assim, as denúncias de reuniões, o "ouvir dizer" e a censura moral foram uma constante, e geraram, sob o rótulo da "leitura sadia", uma divisão tácita de opções de leitura: vidas de santos e romances açucarados para as mulheres e leituras libidinosas para os homens. (MARTINS, 2002, p. 173-174).

\subsection{Constituição de 1891}

No dia 15 de novembro de 1889, o Decreto n. 1 proclamou a República Federativa, e o país passou a ser dirigido por um governo provisório, encabeçado por Deodoro da Fonseca. Em 24 de fevereiro de 1891, a primeira Constituição republicana foi promulgada, erigida sobre o propósito de consolidar o regime republicano e o modo de ser federal do Estado. A Constituição de 1891 criou a Justiça Federal, ao lado da Estadual, colocando o Supremo Tribunal Federal no ápice do Poder Judiciário. Quanto aos juízes, estes não mais poderiam ser suspensos por ato do Executivo, assegurando-lhes a vitaliciedade e a irredutibilidade de vencimentos. (BRANCO, 2015, p. 99).

Quanto à ausência de censura, o art. 72, § 12 era claro ao estatuir que:
A Constituição assegura a brazileiros e a estrangeiros residentes no paíz a inviolabilidade dos direitos concernentes à liberdade, à segurança individual e à propriedade nos termos seguintes: [...] § 12. Em qualquer assumpto é livre a manifestação do pensamento pela imprensa, ou pela tribuna, sem dependencia de censura, respondendo cada um pelos abusos que commetter nos casos e pela fórma, que a lei determinar. Não é permitido o anonymato. (Transcrição ipsis litteris). (CAMPANHOLE; CAMPANHOLE, 1976, p. 76-477).

No entanto, o olhar da mestra e doutora em História Social pelo departamento de História da FFLCH da Universidade de São Paulo, Ana Luíza Martins (2002, p. 174175) é outro: proclamada a República em 15 de novembro de 1889, com receio da reação monárquica, o Governo Provisório baixou em 23 de dezembro de 1889 o primeiro decreto de censura do país, que atingiu diretamente a imprensa. 
Art. $1^{\circ}$ - Os indivíduos que conspirarem contra a República e o seu Governo: que aconselharem ou promoverem, por palavras, escritos ou atos, a revolta civil ou a indisciplina militar; [...] serão julgados militarmente por uma comissão militar nomeada pelo Ministro da Guerra, e punidos com as penas militares de sedição. Art. $2^{\circ}$ Revogam-se as disposições em contrário. Sala das sessões do Governo Provisório, 23 de dezembro de 1889. Marechal Manoel Deodoro da Fonseca - Chefe do Governo Provisório; Benjamin Constant Botelho de Magalhães, Manuel Ferraz de Campos Salles, Rui Barbosa, Eduardo Wandenkolk, Quinto Bocayuva, Demétrio Nunes Ribeiro, Aristides da Silveira Lobo.

O controle da palavra impressa não se limitou ao texto da lei. A repressão do período investiu firme contra formadores de opinião e órgãos de imprensa. O Decreto de 22 de novembro de 1890, que restaurava a liberdade de imprensa, tornou-se ineficaz. Os artigos de Eduardo Prado publicados em A Tribuna contra o Marechal Deodoro da Fonseca e o Exército levaram ao empastelamento daquele jornal, com atos de violenta agressão e morte do revisor João Ferreira Romariz. No entanto, a euforia da belle époque da "política café com leite" acalmou a repressão ao impresso. Mas, durou pouco, e a classe dirigente assim que se sentiu ameaçada pela mesma imprensa que havia alimentado, cuidou de sua repressão. No episódio das "cartas falsas", divulgadas no Correio da Manhã como de autoria do candidato à presidência da República, Arthur Bernardes, este criticava o Exército e punha em risco a aliança paulista e mineira na eleição do sucessor. O Partido Republicano Paulista, diretamente interessado em abafar críticas de toda ordem, reuniu membros do Congresso, propondo a feitura da Lei da Imprensa. A Lei proibia o anonimato, quer nas seções editoriais, quer nas seções livres dos jornais, só permitindo a publicação sem assinatura de simples notícias, avisos, reclames, editais e outros da mesma natureza. Também instituía o direito de resposta nos moldes da legislação francesa. Após contestações, Adolfo Gordo, retirou a lei até o final do ano, para garantir a aprovação do projeto de Orçamento. Ao final, bastante modificada foi aprovada pelo Senado e obteve a sanção presidencial, passando a constituir o Decreto n. 4.743, de 31 de outubro de 1923, conhecido como Lei Adolfo Gordo. Apesar das críticas a Lei de Imprensa estava em vigor, retomando o cerceamento do pensamento, da palavra e da ação durante toda a República. (MARTINS, 2002, p. 174-179).

\subsection{Constituição de 1934}

Sobreveio a Revolução de 1930, culminando as frequentes crises da República Velha. As forças vitoriosas ficaram devendo uma nova Constituição para o país, reclamada com derramamento de sangue, em São Paulo, em 1932. Em 1933, reuniu-se 
uma assembleia constituinte, que redundou no documento constitucional do ano seguinte. (BRANCO, 2015, p. 100).

$\mathrm{O}$ art. 113, n. 9, no Capítulo II, dos direitos e das garantias individuais, trazia a liberdade de expressão sem dependência de censura, salvo quanto a espetáculos e diversões públicas, sendo vedado o anonimato.

Art. 113. A Constituição assegura a brasileiros e a estrangeiros residentes no paiz a inviolabilidade dos direitos concernentes à liberdade, à subsistência, à segurança individual e à propriedade, nos termos seguintes: [...] 9) Em qualquer assumpto é livre a manifestação do pensamento, sem dependência de censura, salvo quanto a espectaculos e diversões publicas, respondendo cada um pelos abusos que commetter, nos casos e pela fórma que a lei determinar. Não é permittido o anonymato. É assegurado o direito de resposta. A publicação de livros e periodicos independe de licença do poder publico. Não será, porém, tolerada propaganda de guerra ou de processos violentos para subverter a ordem politica ou social. (Transcrição ipsis litteris). (CAMPANHOLE; CAMPANHOLE, 1976, p. 422).

\subsection{Constituição de 1937}

De acordo com Paulo Gustavo Gonet Branco (2015, p. 100) a Constituição de 1934 teve curta duração e em 1937, o país já estava sob a Constituição outorgada pelo Presidente Getúlio Vargas, acompanhando o golpe de Estado do mesmo ano. O fundamento da Carta do Estado Novo foi o fortalecimento do Executivo; foi denominada de polaca, devido à influência da Constituição polonesa de linha ditatorial de 1935. O Presidente da República foi habilitado a legislar por decreto-lei. Os direitos fundamentais ganharam referência, no entanto, era apenas simbólica. A pena de morte voltou a ser adotada para crimes políticos e em certos homicídios. Foi institucionalizada a censura prévia da imprensa, tal como se depreende do art. 122, n. 15 “a”: Art. 122.

A Constituição assegura aos brasileiros e estrangeiros residentes no país o direito à liberdade, à segurança individual e à propriedade, nos termos seguintes: [...] 15 - Todo o cidadão tem o direito de manifestar o seu pensamento, oralmente, por escrito, impresso ou por imagens, mediante as condições e nos limites prescritos em lei. A lei pode prescrever: a) Com o fim de garantir a paz, a ordem e a segurança pública, a censura prévia da imprensa, do teatro, do cinematógrafo, da radio-difusão, facultando à autoridade competente proibir a circulação, a difusão ou a representação. 
Marcia Mascarenhas Camargos e Vladimir Sacchetta (2002, p. 207209) trazem duas situações emblemáticas, uma na República Velha e outra durante o Estado Novo envolvendo Monteiro Lobato. Na República Velha, seu embate com Artur Bernardes, em 1924, no rastro da revolução em São Paulo, ao defender o voto secreto e facultativo, diretamente ligado à questão da cidadania, Lobato se tornou alvo de censura pela via da violência no plano econômico. Mais tarde, no Estado Novo, a repressão veio por meio de violência física. Lobato foi encarcerado e volumes de sua obra apreendidos e destruídos em 1937.

Portanto, Lobato atentava contra o programa de educação do governo e contra a defesa nacional, expondo as crianças a doutrinas perigosas e práticas deformadoras do caráter. Assim, com fulcro no art. $5^{\circ}$ do Decreto-Lei n. 431, de 18 de maio de 1938, os livros foram retirados das bibliotecas escolares do Distrito Federal e queimados em fornalhas. (CAMARGOS; SACHETTA, 2002, p. 219-235).

De acordo com Maria Luiza Tucci Carneiro (2002, p. 263-264), ao estudar a história da censura, em qualquer tempo da história e de qualquer país, percebe-se que tanto os homens do poder quanto os revolucionários sempre tiveram consciência da força da palavra. É pelo discurso oral ou escrito que as ideias circulam reelaborando valores e gerando novas atitudes. A polícia política, criada em 1924 na época da vigência da República Velha, foi a responsável, por mais de seis décadas, pelo controle das ideias e pela repressão aos cidadãos considerados perigosos à ordem instituída.

A queda do Estado Novo, após o final da Segunda Guerra Mundial, traz uma nova configuração ao país. Houve eleições gerais com a participação dos partidos políticos e três candidatos concorrem à presidência da República. Assim, o general Eurico Gaspar Dutra, ex-ministro da Guerra de Getúlio é o eleito. Em janeiro de 1946, pelo Decreto n. 20.493 é criado o Serviço de Censura de Diversões Públicas do Departamento Federal de Segurança Pública (mais tarde Polícia Federal), tendo estrutura e procedimentos vigorados por muitos anos, sobrevivendo ao advento do AI-5, no final de 1968. O decreto é anterior à promulgação da Constituição de 1946, que restabelece o estado de direito em toda a sua extensão. (SIMÕES, 2002, p. 352).

\subsection{Constituição de 1946}

A Constituição de 1946 reinstalou a democracia representativa, com o poder sendo exercido por mandatários escolhidos pelo povo e por prazo certo. Retomou-se a fórmula federal do Estado, assegurando-se a autonomia aos Estados-membros. Embora a Constituição fosse presidencialista, no período de setembro de 1961 a janeiro de 1963 foi implantado o parlamentarismo, implantado pela Emenda n. 4, a fim de amenizar a crise política que se seguiu à renúncia de Jânio Quadros à Presidência da República. Foram 
excluídas as penas de morte, de banimento e do confisco. As vigas principais da ordem econômica eram: os princípios da justiça social, da liberdade de iniciativa e da valorização do trabalho. O direito de greve apareceu expresso no Texto Constitucional. (BRANCO, 2015, p. 101).

No Capítulo II, Dos Direitos e das Garantias Individuais, o art. 141, $\S 5^{\circ}$ retoma o texto da Constituição de 1934, com algumas modificações:

\begin{abstract}
Artigo 141. A Constituição assegura aos brasileiros e aos estrangeiros residentes no país a inviolabilidade dos direitos concernentes à vida, à liberdade, à segurança individual e à propriedade, nos têrmos seguintes: [...] $\S 5^{\circ}$ É livre a manifestação do pensamento, sem que dependa de censura, salvo quanto a espectáculos e diversões públicas, respondendo cada um, nos casos e na forma que a lei preceituar, pelos abusos que cometer. Não é permitido o anonimato. É assegurado o direito de resposta. A publicação de livros e periódicos não dependerá de licença do poder público. Não será, porém, tolerada propaganda de guerra, de processos violentos para subverter a ordem política e social, ou de preconceitos de raça ou de classe. (ipsis litteris).
\end{abstract}

Até 1955, são poucos os questionamentos envolvendo a liberação de filmes. Mas, a atuação da censura vai para as primeiras páginas e ganha repercussão até no exterior em 1955 quando Nelson Pereira dos Santos requer um certificado para exibir Rio 40 Graus. Nelson inverte a equação habitual, oferecendo um cartão-postal às avessas, mostrando o brasileiro comum nas telas. A proibição do filme em todo o território nacional teve como fundamento que "as várias histórias que compõem o referido filme apresentam tipos de delinquentes, viciosos e marginais, cuja conduta em certo ponto é até enaltecida". Além disso, o filme foi feito com tal habilidade que serve aos interesses políticos do extinto PCB (Partido Comunista Brasileiro). "A figura do coronel do interior, inculto e boçal, apresentado como deputado federal significava um achincalhe imperdoável à Câmara dos Deputados". E havia também um sacrilégio: no exato momento em que aparece o Cristo Redentor, a música de Zé Keti de fundo diz: "eu sou o rei dos terreiros". É preciso deixar consignado que o filme se tornou uma referência fundamental na história do cinema brasileiro, tendo influenciado gerações de cineastas, além de estar incluído em todas as antologias. (SIMÕES, 2002 p. 353-356).

Outro filme bastante polêmico, de 1962, foi "Os Cafajestes" dirigido por Ruy Guerra, com Norma Bengell, Daniel Filho e Jece Valadão nos papéis principais. O longa-metragem conta a história de dois rapazes da zona sul e suas vidas sem rumo, em meio a bebida, drogas, curras, etc. Tais episódios não constituíam mais novidade para o público depois da extensa cobertura da imprensa sobre o caso Aída Curi. Proibido e liberado inúmeras vezes, "Os Cafajestes" tornou-se um emblema da luta entre o novo 
cinema e o conservadorismo de associações católicas e burocratas medíocres. Outros temas também eram considerados proibidos tais como: o divórcio, o adultério, a nudez, a visão não cor-de-rosa de mundo e o humor. (SIMÕES, 2002, p. 358-359).

Em agosto de 1962 é instituído, pela Lei n. 4.117, o Código Brasileiro de Telecomunicações. $\mathrm{O}$ art. 53 trata do abuso no exercício de liberdade da radiodifusão. Cabe destacar o abuso por ultrajar a honra nacional; ofender a moral familiar, pública, ou os bons costumes; caluniar, injuriar ou difamar os poderes Legislativo, Executivo ou Judiciário ou os respectivos membros.

\subsection{Constituição de 1967}

Depois de um período de conturbação política, as Forças Armadas, em março de 1964, intervieram na condução do país por meio de atos institucionais e por uma sucessão de emendas à Constituição de 1946. Em 1967, o Congresso Nacional aprovou uma nova Constituição, marcada pela tônica da preocupação com a segurança nacional. Tal conceito, de reconhecida vagueza, tinha por eixo básico a manutenção da ordem, sobretudo onde pudesse existir a atuação de grupos de tendência de esquerda, especialmente comunista. A Constituição de 1967 dava ao Presidente da República muitos poderes, podendo legislar por meio de decretos-leis. (BRANCO, 2015 p. 101). Com relação à censura, em seu art. $150, \S 8^{\circ}$ deixava claro que:

É livre a manifestação de pensamento, de convicção política ou filosófica e a prestação de informação sem sujeição a censura, salvo quanto a espetáculos e diversões públicas, respondendo cada um, nos termos da lei, pelos abusos que cometer. É assegurado o direito de resposta. A publicação de livros, jornais e periódicos independe de licença da autoridade. Não será, porém, tolerada a propaganda de guerra, de subversão da ordem ou de preconceitos de raça ou de classe.

A regulamentação da imprensa veio com a Lei n. 5.250 de 9 de fevereiro de 1967. Com relação à censura estabelece que:

Art. $1^{\circ}$ É livre a manifestação do pensamento e a procura, o recebimento e a difusão de informações ou ideias, por qualquer meio, e sem dependência de censura, respondendo cada um, nos termos da lei, pelos abusos que cometer. $\S 1^{\circ}$ Não será tolerada a propaganda de guerra, de processos de subversão da ordem política e social ou de preconceitos de raça ou classe. $\S 2^{\circ} \mathrm{O}$ disposto neste artigo não se aplica a espetáculos e diversões públicas, que ficarão sujeitos à censura, na forma da lei, nem na vigência do estado de sítio, quando o Governo poderá exercer a censura sobre os jornais ou periódicos e empresas de radiodifusão e 
agências noticiosas nas matérias atinentes aos motivos que o determinaram, como também em relação aos executores daquela medida.

A violação de alguns preceitos será considerada crime, com previsão de penas que variam de 1 mês a 4 anos de detenção e em outros, com penas mais severas, podendo chegar a 10 anos de reclusão. Citamos como exemplos: "Art. 17. Ofender a moral pública e os bons costumes: Pena: Detenção de 3 meses a 1 ano e multa de 1 a 20 salários-mínimos da região".

Porém, a crise política se agravou nos anos subsequentes e em 13 de dezembro de 1968, o Governo editou o Ato Institucional n. 5, que ampliava extremamente os poderes do Presidente da República, ao mesmo tempo em que tolhia mandatos políticos e restringia direitos e liberdades básicos. Os atos praticados com fulcro nesse Ato ficavam imunes ao controle do Judiciário. (BRANCO, 2015, p. 101).

Assim, com o intuito de "assegurar a continuidade da obra revolucionária" o AI-5 institucionaliza a ditadura. São mantidas a Constituição de 1967 e as Constituições estaduais, porém com as modificações constantes do Ato Institucional n. 5, podendo o Presidente da República, no interesse nacional, decretar a intervenção nos Estados e Municípios, sem as limitações previstas na Constituição. Também no interesse de preservar a Revolução, o Presidente da República, ouvido o Conselho de Segurança Nacional, e sem as limitações previstas na Constituição, poderá suspender os direitos políticos de quaisquer cidadãos pelo prazo de 10 anos e cassar mandatos eletivos federais, estaduais e municipais. As garantias constitucionais ou legais de vitaliciedade, inamovibilidade e estabilidade, ficam suspensas. Na luta contra a corrupção, o Presidente da República poderá, após investigação, decretar o confisco de bens de todos quantos tenham enriquecido, ilicitamente, no exercício de cargo ou função pública, inclusive de autarquias, empresas públicas e sociedade de economia mista, sem prejuízo das sanções penais cabíveis. Suspende-se a garantia de habeas corpus, nos casos de crimes políticos, contra a segurança nacional, a ordem econômica e social e a economia popular.

\subsection{Constituição de 1969}

Em 1969, depois de declarada a incapacidade por motivo de saúde do Presidente da República, Arthur da Costa e Silva, a Junta composta pelos Ministros que chefiavam cada uma das três Armas (Exército, Marinha e Aeronáutica), assumiu o governo e por meio da Emenda Constitucional n. 1/69 promoveu uma grande reforma da Constituição de 1967. Muitos autores veem na Emenda n. 1/69 uma nova Constituição outorgada pela Junta Militar. (BRANCO, 2015, p. 101). 
Com relação à censura, a Constituição de 1969 , em seu art. $153, \S 8^{\circ}$ assegurava que:

É livre a manifestação de pensamento, de convicção política ou filosófica, bem como a prestação de informação independentemente de censura, salvo quanto a diversão e espetáculos públicos, respondendo cada um, nos termos da lei, pelos abusos que cometer. É assegurado o direito de resposta. A publicação de livros, jornais e periódicos não depende de licença da autoridade. Não serão, porém, toleradas a propaganda de guerra, de subversão da ordem ou de preconceitos de religião, de raça ou de classe, e as publicações e exteriorizações contrárias à moral e aos bons costumes.

O Decreto-Lei n. 1.077, de 26 de janeiro de 1970 regulamentou o art. 153, $\S 8^{\circ}$, da Constituição de 1969. Valorizava a instituição da família, a formação sadia e digna da mocidade, e combatia o amor livre que ameaçava destruir os valores morais da sociedade brasileira. Também eram combatidas as revistas com publicações obscenas, canais de televisão que executassem programas contrários à moral e aos bons costumes e planos subversivos que poriam em risco a segurança nacional. Instituía a censura prévia, cabendo ao Ministério da Justiça, por meio do Departamento de Polícia Federal, verificar, quando julgasse necessário, antes da divulgação de livros e periódicos, a existência de matéria infringente à moral e aos bons costumes. Portanto, verificada a existência de matéria ofensiva à moral e aos bons costumes, o Ministro da Justiça deveria proibir a divulgação e determinar a busca e apreensão de todos os seus exemplares.

A censura de diversões públicas coube à Polícia Federal, por meio da Divisão de Censura de Diversões Públicas (DCDP), de acordo com o Decreto n. 73.332, de 19 de dezembro de 1973, que define a estrutura do Departamento de Polícia Federal.

Com relação aos direitos autorais, apesar da censura, a Lei n. 5.988, de 14 de dezembro de 1973, revogada pela Lei n. 9.610 de 1988, trazia uma parte benéfica aos autores, pois previa em seu art. $73, \S 2^{\circ}$ que o empresário deveria apresentar à autoridade policial, o programa, acompanhado da autorização do autor, intérprete ou executante e do produtor de fonogramas, bem como o recibo de recolhimento ou documento equivalente em forma autorizada pelo Conselho Nacional de Direito Autoral, a favor do Escritório Central de Arrecadação e Distribuição, o valor dos direitos autorais para a aprovação do espetáculo ou da transmissão.

Na prática, com o golpe militar de 1964, a situação piorou muito para os cineastas brasileiros porque tinha havido um deslocamento, pois o mal a ser combatido não era mais a imoralidade e a indecência. Agora, tratava-se do perigo vermelho, ameaça mais difusa contra qual todos tinham que estar atentos, pois o comunismo era uma espécie de hidra com várias cabeças, apresentando-se sob várias formas. Não se pode esquecer 
que até a edição do AI-5 a censura teve sua atuação inúmeras vezes contestada na Justiça. Assim, produtores e cineastas (ou distribuidores dos filmes estrangeiros mutilados pela tesoura paranoica) obtinham decisões favoráveis por meio do Poder Judiciário. (SIMÕES, 2002, p. 359-362).

\section{A Censura e a Jurisprudência dos Tribunais}

De acordo com Maria Aparecida de Aquino (2002, p. 516-517), no Brasil, o exercício da censura, de forma constante e institucionalizada, ocorreu no primeiro governo Vargas (1930-1945), especialmente durante a vigência do Estado Novo (19371945), e no regime militar (1964-1985), principalmente no seu período de maior repressão (1968-1978).

Desde o golpe de 1964 houve uma preocupação com o armazenamento de informações e a divulgação destas para a população. Podem ser citadas a criação do Serviço Nacional de Informações (SNI), em 1964, e no final da década, a estruturação dos centros de informação do Exército (CIE), da Aeronáutica (Cisa) e da Marinha (Cenimar). No entanto, a partir do segundo semestre de 1968, devido ao aumento das tensões entre Estado e sociedade civil, e o acirramento das relações no interior das próprias Forças Armadas, desencadeia-se o aumento do controle sobre todos os órgãos de divulgação.

Com o objetivo de controle, a censura agiu de duas formas. A primeira, por meio de telefonemas ou bilhetes para as redações dos jornais, a fim de impedir a veiculação de determinadas informações, utilizando a fórmula clássica: "De ordem superior, fica terminantemente proibido noticiar que...". Caso o jornal resolvesse acatar a ordem, a responsabilidade pela censura, no interior do jornal, passava a ser assumida por sua direção e não mais pelos órgãos do governo. Tal atitude pode ser chamada de autocensura. A segunda forma ocorria quando as ordens não eram aceitas ou era necessário um maior controle de determinado órgão de divulgação, instaurando-se então a censura prévia. Assim, de outubro de 1968 a aproximadamente maio de 1969, a censura ficou diretamente a cargo das Forças Armadas. Depois, a censura institucionalizou-se e passou para a alçada do Ministério da Justiça e para a atuação da Polícia Federal que encarregava os Departamentos de Polícia Federal nos diferentes Estados do Brasil de realizar tal função, por meio de agentes especialmente instruídos para o exercício do cargo, isto é, os censores. (AQUINO, 2002 p. 518-519).

Maria Aparecida Aquino (2002, p. 521) cita dois jornais que optaram pela aceitação das ordens por meio de bilhetes e telefonemas à redação: a Folha de São Paulo (SP) e o Jornal do Brasil (RJ). A justificativa era de que dessa forma conseguiriam passar "nas entrelinhas" muito mais informações ao leitor do que se adotassem uma atitude mais dura, que desse origem à imposição da censura prévia na redação. É de se observar que 
na censura prévia houve a produção da matéria jornalística, bem como o veto do censor, enquanto que na autocensura apenas houve a decisão, na obediência a ordens superiores de não se publicar determinada matéria.

Enquanto a censura do Estado impede o exercício da liberdade, sem necessariamente afetar a dignidade do jornalista, a autocensura vai minando a integridade do ser, pois ele aceita a restrição a sua liberdade e se torna ao mesmo tempo agente e objeto da repressão. Ao autocensurar-se, o jornalista afere e decide o que é bom ou não para o leitor. Assim, condiciona a socialização da verdade a uma avaliação prévia das consequências da verdade. Porém, a única forma consciente das autocensuras no jornalismo das democracias liberais em tempos de paz é a aplicada para evitar processos indenizatórios na justiça, como, por exemplo, conflito entre o direito de informação e o direito à privacidade. Tais casos são analisados com a participação de advogados e não têm o objetivo de iludir o leitor e sim criar condições seguras para maximizar a divulgação da verdade. (KUCINSKI, 2002, p. 538-540).

Passemos então à discussão dos casos emblemáticos do Tribunal Federal de Recursos:

1. Mandado de Segurança n. 74.626-DF (Caso Calabar), Relator Ministro José Néri da Silveira, Requerente Francisco Buarque de Holanda, Requerido Exmo. Sr. Diretor-Geral do Departamento de Polícia Federal. Data do julgamento: 16 de maio de 1974.

Em breve síntese, o caso trata do mandado de segurança impetrado por Francisco Buarque de Holanda que em parceria com o teatrólogo e cineasta Ruy Guerra, escreveu a peça teatral Calabar, o Elogio da Traição, para ser encenada em um dos teatros da cidade do Rio de Janeiro. Após submetê-la ao Serviço de Censura de Diversões Públicas do Departamento de Polícia Federal, em 25 de julho de 1973 foi expedida autorização com a classificação de imprópria para menores de 18 anos. Estando a peça em preparação e ao ficar pronta para ser levada à cena, foi o órgão cometente provocado a marcar data para o ensaio geral, recebendo nessa oportunidade a empresária a comunicação de que a peça deveria ser reexaminada por autoridade superior. Ao final, o Diretor-Geral do Departamento de Polícia Federal proibiu a apresentação da peça em todo o território nacional, de acordo com o disposto no art. 41, alínea "g", do Decreto n. 20.493, de 24 de janeiro de 1946, in verbis: Art. 41. Será negada a autorização sempre que a exibição ou transmissão radiotelefônica: [...] g) ferir, por qualquer forma, a dignidade ou o interesse nacionais. $\mathrm{O}$ impetrante defende que a peça não ofende a dignidade ou a interesses nacionais. Ao contrário, transcrevendo trechos da mesma peça, busca a autoridade evidenciar os aspectos de inversão de valores, de desprestígio aos vultos históricos e de enaltecimento de um traidor, "para conduzi-lo à situação de um herói nacional". "Em 1632 dois acontecimentos importantes auxiliaram os holandeses: 
vieram reforços da Holanda e houve a traição de Domingos Fernandes Calabar, profundo conhecedor da região, que passou a colaborar com eles" (HOLANDA, 1972, v. 1, p. 58). Dessa forma, procedido o reexame, constatado ficou que a peça em tela é conduzida, pelo seu texto, para uma área controvertida, com a ridicularização de vários heróis da nossa história, elementos fundamentais da formação da nacionalidade brasileira, em que uma das bases encontramos exatamente no episódio da luta contra a dominação holandesa no Nordeste, enquanto, por outro lado, enaltece aquele que fora incontestavelmente traidor, de acordo com o relatório do Relator Ministro José Néri da Silveira. Ao final foi denegado o mandado de segurança, contra os votos dos Srs. Ministros Jarbas Nobre e Peçanha Martins, em 16/05/1974. (BRASIL. Tribunal Federal de Recursos, 1988, p. 53-68).

2. Mandado de Segurança n. 94.746-DF (Caso Rimas Sádicas), Relator Sr. Ministro José Cândido, Requerente Jurandyr C. Chaves, Requerido: Ministro de Estado da Justiça. Julgado em 18 de dezembro de 1981.

Em síntese, Jurandyr C. Chaves, de nome artístico “Juca Chaves” impetrou mandado de segurança contra ato do ministro da Justiça "que interditou, para veiculação no Rádio e TV, a música Rimas Sádicas, em despacho publicado no Diário Oficial da União, de 5 de agosto de 1981". Esclarece o postulante que tendo sido interditada a sua música Beijo com Beijo, melhorou a letra e voltou ao Conselho Superior de Censura, obtendo total liberação do novo texto, agora com a denominação de Rimas Sádicas. Porém, o seu Presidente recorreu ao Exmo. Sr. Ministro da Justiça, que por meio do ato impugnado lhe impediu de divulgar a sua música através do Rádio e TV. Pretendendo a reforma do ato, que considera ofensivo à sua liberdade de expressão artística, vem o autor a esta egrégia Corte, dizendo-se ainda prejudicado nos seus interesses econômicos e profissionais. Em voto do Relator, ministro José Cândido asseverou que é necessário que a Corte tome conhecimento do texto das Rimas Sádicas, fruto da inteligência do cancioneiro. E concluiu que há, no texto em exame, algumas expressões fortes, embora já divulgadas, como lembra a impetração, em músicas de Roberto Carlos, Chico Buarque de Holanda e Rita Lee. Pouco importa que alguns artistas tenham abusado da censura. O argumento é que não é válido para convencer a Justiça. A verdade é que há espalhadas na letra da canção algumas “exteriorizações contrárias à moral e aos bons costumes”, por isso que não toleradas, expressamente pelo $\S 8^{\circ}$, do art. 153, da Constituição Federal e arts. $1^{\circ} \mathrm{e}$ $7^{\circ}$, do Decreto-Lei n. 1.077, de 26/01/1970. É necessário que se acentue que a moral, pelo que ela representa de ato decente, educativo e instrutivo embora desvinculada do direito, não pode ser ofendida com a omissão do censor e com o beneplácito da Justiça. Assim, a agressão total ao pudor público, no que ele representa de decência média da sociedade e dos bons costumes, não pode ser aceita. É necessário compreender que o Rádio e a Televisão se transformaram nos mais eficientes veículos de comunicação social, pela liberdade com que ingressam nos lares e nos ambientes sociais mais fechados. Por isso, sobre eles deve 
recair a maior parcela de vigilância do censor. O impetrante há de convir que já lhe foi permitido o suportável pela moral e pelo direito, ou seja, a liberação apenas para Show. Há, na modinha do cancioneiro, palavras inconvenientes e ofensivas à sensibilidade do ouvinte de rádio, e do telespectador afeitos aos hábitos morigerados da vida em sociedade. Há também necessidade de se proteger a infância. Com tais fundamentos foi denegada a segurança. Em voto vencido, o Sr. Ministro Américo Luz explanou que havendo a censura permitido anteriormente a divulgação de letras de músicas, citadas nos autos, de autoria de Roberto Carlos e Rita Lee, entendeu que não se poderia dispensar tratamento diferente ao que é objeto da segurança impetrada. Ao final, o Tribunal, por maioria de votos, vencido o Sr. Ministro Américo Luz, denegou o mandado de segurança. (BRASIL. Tribunal Federal de Recursos, 1988, p. 149-156).

\section{A Constituição atual e a censura}

Como foi visto a censura tem um caráter perverso. Ela destrói em nome da segurança, da moral, da família e dos bons costumes. A censura demonstra um receio do Estado de que o povo não seja capaz de julgar por si.

Nos dias atuais, a censura é caracterizada como um verdadeiro ilícito constitucional, e é ato inerentemente injusto, arbitrário e discriminatório.

A atual Constituição assegura, em seu art. $5^{\circ}$, IX, a liberdade de expressão da atividade intelectual, artística, científica e de comunicação, independentemente de censura ou licença.

A liberdade de expressão, entendida como direito fundamental, tem, principalmente, um caráter de pretensão de que o Estado não exerça a censura. Portanto, não é o Estado que deve estabelecer quais as opiniões válidas e aceitáveis, porque essa tarefa cabe ao público a que essas manifestações se dirigem. Pode-se dizer que a liberdade de expressão é um corolário da dignidade humana. O pluralismo de opiniões é vital para a formação da vontade livre, logo a liberdade de expressão é enaltecida como instrumento para o funcionamento e preservação do sistema democrático. O ser humano se constitui no contato com o seu semelhante e o direito de se comunicar livremente conecta-se com a característica da sociabilidade, que é essencial ao ser humano. (BRANCO, 2015, p. 264-265).

De acordo com José Afonso da Silva (2014, p. 100), não se pode esquecer que o dispositivo acima (art. $5^{\circ}$, IX) se conecta ao texto do inciso IV (liberdade de manifestação do pensamento); ao art. 206, II ("liberdade de aprender, ensinar, pesquisar e divulgar o pensamento, a arte e o saber"); ao art. 215 (liberdade de expressão cultural); ao art. 220 (“a manifestação, a criação, a expressão e a informação, sob qualquer forma, processo ou veículo não sofrerão qualquer restrição, observado o disposto nesta 
Constituição"); ao $\S 1^{\circ}$ desse art. 220, que veda qualquer "embaraço à plena liberdade de informação jornalística" (forma de manifestação do pensamento); ao $\S 2^{\circ}$ do art. 220, vedando "toda e qualquer censura de natureza política, ideológica e artística"; ao $\S 3^{\circ}$ do dispositivo, que permite alguma restrição a uma forma de expressão artística (diversões e espetáculos públicos); e ao seu $\S 6^{\circ}$, que garante a publicação de veículo impresso de comunicação sem licença de autoridade.

Portanto, o princípio geral na matéria é a ampla liberdade de expressão, só se admitindo as restrições fundadas na própria Constituição, como declina o próprio art. 220 “caput” e parágrafos $1^{\circ}, 2^{\circ}$ e $3^{\circ}$. E, realmente, há a previsão expressa da restrição à liberdade de imprensa, radiodifusão e televisão, na forma da lei, no art. 139, III, que trata do estado de sítio.

A Constituição de 1988, ao repudiar a solução autoritária da censura prévia deu mecanismos de proteção aos valores éticos e sociais da pessoa e da família, conforme se depreende dos arts. 221, IV e 220, $\S 3^{\circ}$, II.

Como se sabe, valores éticos e sociais da pessoa e da família são noções que variam no tempo e no espaço além de serem percebidas de forma distinta pelos indivíduos, mesmo contemporâneos. Assim, caberá ao Poder Judiciário, diante do caso concreto e garantido o devido processo legal, decidir a melhor solução.

\subsection{Controle da programação de televisão na Constituição de 1988}

Em relação à televisão permanece, como regra, a liberdade de escolha. A pessoa pode mudar de canal ou desligar o aparelho exigindo um comportamento proativo.

A única situação especial ocorre com a possibilidade de a mensagem televisiva atingir público de menor maturidade ou discernimento, sujeitando-o a efeitos socialmente indesejáveis na sua formação ou no seu comportamento. Portanto, há necessidade de proteger este público. No entanto, nem aqui é admitida a restrição ao conteúdo de expressão. O que é permitido é a utilização de mecanismos razoáveis que minimizem o risco de acesso à mensagem por parte do público ainda incapaz. Assim, os mecanismos de controle fazem a verificação do cumprimento das normas gerais e abstratas preexistentes, constantes da Constituição e dos atos normativos legitimamente editados, e eventual imposição de consequências jurídicas pelo seu descumprimento. (BARROSO, 2001, p. 132).

No Brasil, há previsão constitucional do controle administrativo, de acordo com o art. 21, XVI que concede à União competência para exercer a classificação para efeito indicativo, por faixas etárias, de diversões públicas e de programas de rádio e televisão. 
Além do controle administrativo, com previsão constitucional no art. 21, XVI, há o controle judicial, por força do mandamento constitucional previsto no art. $5^{\circ}$, $\mathrm{XXXV}$, que consagra o direito de ação a todo aquele que se suponha lesado ou ameaçado em seu direito. $\mathrm{O}$ exercício da liberdade de expressão pode, em certas situações, violar a ordem jurídica e afetar a esfera de direitos de outrem, sujeitando, desse modo, o agente a consequências jurídicas de natureza civil ou penal. Não se pode, neste caso, falar em censura, pois o controle judicial é fundado na independência e imparcialidade do órgão que o exerce, e obedece a um devido processo legal, que inclui o direito ao contraditório e à ampla defesa, com os meios e recursos a ela inerentes (art. $5^{\circ}$, LIV e LV). A Constituição assegura direitos que podem ser afetados pelo exercício abusivo da liberdade de expressão, tais como, o direito à honra ou à imagem, e, ocorrendo tal violação, o titular desses direitos pode demandar em juízo em busca da reparação devida, que poderá ser de natureza material e moral, como previsto na Carta de 1988 (art. 5, $\mathrm{X}$ ). Caso sejam violados direitos difusos e coletivos, caberá o ajuizamento de ação civil pública. (BARROSO, 2001, p. 133-134).

Não há dúvida de que o princípio geral na matéria é a ampla liberdade de expressão, sendo este o vetor de toda a atividade interpretativa (arts. $5^{\circ}$, IV e 220, caput e $\S 1^{\circ}$ ). Porém, são admitidas as restrições fundadas na própria Constituição, como declina o próprio art. 220, caput, parte final. A Constituição estabeleceu duas regras específicas sobre a matéria: 1) proibiu a censura, isto é, a possibilidade de o Estado, por seus órgãos administrativos e em virtude de um poder geral de polícia, alterar, de alguma forma, o conteúdo ou qualquer decisão relacionada com a exibição de programa por instituição privada e, 2) proibiu a subordinação das exibições e publicações a qualquer espécie de licença prévia (arts. $5^{\circ}$, IX e $220, \S 2^{\circ}$ ).

\subsection{ADI n. 2.404 - Ação Direta de Inconstitucionalidade}

O tema envolve o complexo fenômeno do controle dos meios de comunicação na sociedade moderna, especialmente a televisão, sob a ótica da Constituição e dos valores que ela consagra e protege. O professor Luís Roberto Barroso analisa se é constitucional ou não a previsão constante do art. 254, da Lei n. 8.069, de 13/07/1990, denominada Estatuto da Criança e do Adolescente, objeto da Ação Direta de Inconstitucionalidade (ADI n. 2.404) que prevê:

Art. 254. Transmitir, através de rádio ou televisão, espetáculo em horário diverso do autorizado ou sem aviso de sua classificação. Pena - multa de vinte a cem salários de referência; duplicada em caso de reincidência a autoridade judiciária poderá determinar a suspensão da programação da emissora por até dois dias. 
A Constituição de 1988, em seu art. 227 assegura um tratamento especial às crianças e aos adolescentes. Foi também no interesse dos menores que a Carta instituiu a classificação indicativa, permitindo que pais e responsáveis pudessem estar advertidos do conteúdo da programação. No entanto, o Estatuto da Criança e do Adolescente (ECA), Lei n. 8.069/90 desbordou do limite autorizado pela Lei Maior, ao tipificar como infração a seguinte conduta: "Transmitir, através de rádio ou televisão, espetáculo em horário diverso do autorizado (...)". Porém, a classificação a ser veiculada pelas emissoras é apenas indicativa, isto é, não obrigatória. A União só dispõe de competência para indicar uma classificação e não pode vincular nem proibir. Desse modo, a simples inobservância do horário recomendado na classificação exercida pelo Poder Público não pode, por si só, gerar qualquer espécie de sanção, pois assim a sanção não seria indicativa, mas cogente. Não é possível concluir que indicativo é obrigatório. A emissora tem o direito de discordar da classificação imposta pela Administração, embora tenha o dever de informá-la aos seus telespectadores. Desse modo, poderá exibir em horário diverso do recomendado, por entender equivocado o horário sugerido. Isso porque não existe horário autorizado, o que pressuporia a necessidade de uma autorização prévia, vedada de forma expressa pela Constituição (art. $5^{\circ}$, IX). É importante deixar claro que as emissoras podem eventualmente estar sujeitas à punição ou restrição por violação dos princípios do art. 221, na forma da lei e assegurado o devido processo legal. Nunca previamente e, menos ainda, pela atuação unilateral do Poder Público. E conclui o professor Barroso que: "não é compatível com a Constituição a previsão do art. 254 do Estatuto da Criança e do Adolescente de que será punida a transmissão de espetáculo em horário diverso do autorizado, porque: i) o texto constitucional se refere apenas a classificação indicativa; ii) a autorização caracterizaria exame prévio de conteúdo, o que é vedado. (BARROSO, 2001, p. 149-152).

A ADI n. 2.404 foi proposta em 6 de fevereiro de 2001, pelo Partido Trabalhista Brasileiro (PTB) para impugnar o art. 254 da Lei n. 8.069/90 (Estatuto da Criança e do Adolescente) por contrariar normas da Constituição da República (art. 21, XVI, art. $5^{\circ}$, IX e art. 220 e parágrafos).

O partido requerente alega a inconstitucionalidade da expressão "em horário diverso do autorizado" por entender que viola o direito fundamental da liberdade de expressão e da livre manifestação do pensamento. Em síntese, a lei não pode, sem gravíssima ofensa à Constituição, transformar a classificação indicativa ou informativa em ato de permissão ou autorização, de modo a criar hipóteses de proibição para impor penalidades. No mais, o PTB considera que ao Poder Público somente cabe informar o conteúdo do programa que será transmitido e utilizar a classificação para efeito meramente indicativo e não de "censura prévia". O julgamento da ADI foi iniciado em 30 de novembro de 2011 com o voto do Ministro Relator Dias Toffoli (Relator), que julgou procedente a ação, para declarar a inconstitucionalidade da expressão "em horário diverso 
do autorizado" contida no art. 254 da Lei n. 8.069/90. Também votaram pela procedência do pedido os Ministros Luiz Fux, Cármen Lúcia e Ayres Britto (aposentado), a fim de permitir que as emissoras definam livremente sua programação, sendo obrigadas somente a divulgar a classificação indicativa realizada pelo governo federal. Em 5 de novembro de 2015, o Ministro Edson Fachin sucedeu o Ministro Joaquim Barbosa (aposentado), que havia pedido vista dos autos em novembro de 2011. Fachin votou pela procedência da ADI, porém deu interpretação conforme a Constituição, sem redução de texto, à expressão “em horário diverso do autorizado". "O vocábulo 'autorizado' é nulo apenas se utilizado no sentido de permitir ao Poder Público que impeça, discricionariamente, a exibição de um programa de televisão", disse. No entanto, avaliou que a expressão questionada será compatível com a Constituição Federal quando tratar sobre a faixa de horários. Assim, conforme o Ministro Edson Fachin, é cabível a sanção prevista no art. 254 do ECA para a exibição de programa sem classificação indicativa ou em desacordo com ela ou fora do horário indicado para a exibição. Nas palavras do Ministro, "liberdade de expressão e proteção das crianças não são incompatíveis". Para ele, "esta restrição pontual à liberdade de expressão pode existir em função do que estabelece o artigo 227 da CF”, que garante prioridade absoluta para as crianças e afirma o papel do Estado e da sociedade para protegê-la de todas as formas de violência. Deixou muito claro, que a política brasileira de Classificação Indicativa está em consonância com o Direito Internacional e com os padrões internacionais de liberdade de expressão. Ou alguém acha que todos esses países censuram os meios de comunicação? Depois do voto do ministro Fachin, o ministro Teori Zavascki pediu vista, e em 12 de fevereiro de 2016 houve a devolução dos autos para julgamento. Finalmente, em 31 de agosto de 2016, o Supremo Tribunal Federal, por maioria e nos termos do voto do Relator Ministro Dias Toffoli, julgou procedente o pedido formulado na ação direta para declarar a inconstitucionalidade da expressão “em horário diverso do autorizado", contida no art. 254, da Lei n. 8.069/90, vencido, em parte, o Ministro Marco Aurélio, que julgava procedente em maior extensão, e os Ministros Edson Fachin, Rosa Weber e Ricardo Lewandowski (Presidente), que davam interpretação conforme ao dispositivo impugnado. Não votou o Ministro Roberto Barroso por suceder ao Ministro Ayres Britto. (ADI n. 2.404, 2016).

5. O caso das bibliografias não autorizadas: é censura?

Ensina a professora Silmara Juny de Abreu Chinellato (2016, p. 208) que não há direito absoluto, nem ilimitado, havendo a necessidade de ponderações. Vejamos: a liberdade de expressão está fundamentada no art. $5^{\circ}$, IV e IX e a liberdade de informação, no art. $5^{\circ}, \mathrm{XIV}$, os quais se enquadram entre os direitos e garantias fundamentais. A liberdade de expressão é subjetiva (criação intelectual) e direito à informação é objetivo. $\mathrm{O}$ art. 220 
reforça que "A manifestação do pensamento, a criação, a expressão e a informação, sob qualquer forma, processo ou veículo não sofrerão qualquer restrição, observado o disposto nesta Constituição". Enquanto o parágrafo $2^{\circ}$ enfatiza a proibição de censura, o parágrafo $1^{\circ}$ expressamente impõe a observância do disposto no art. $5^{\circ}, \mathrm{IV}, \mathrm{V}, \mathrm{X}, \mathrm{XIII}$ e XIV. O inciso XIII garante o exercício de qualquer trabalho, ofício ou profissão. Os incisos V e X limitam ou restringem a liberdade de expressão em favor da pessoa retratada.

Assim, nem sempre é fácil solucionar o conflito entre dois direitos consagrados, tais como os direitos à vida privada, à intimidade, ao segredo, à honra e à imagem e a liberdade de expressão. A colisão de direitos dessa natureza deve ser sopesada segundo o princípio da proporcionalidade. Acrescente-se que o direito à informação não é absoluto, encontrando o direito à informação, relativa a qualquer pessoa, limitações ainda maiores. (CHINELLATO, 2016, p. 214-215).

No entender da professora Silmara Chinellato (2016, p. 217) uma boa diretriz a ser ponderada, no caso concreto, é expurgar da obra trechos polêmicos, não necessários à espinha dorsal, contribuindo assim, para que a obra não seja proibida ou retirada de circulação.

Além disso, a pessoa notória não renuncia à sua vida privada e devemos lembrar que a lesão a direitos da personalidade do biografado não são reparáveis, mas, meramente compensáveis. Portanto, um acordo prévio e conciliatório entre biógrafo e biografado seria o ideal.

É preciso reconhecer a possibilidade de acionar o Judiciário após a publicação da biografia em caso de ofensa aos direitos no âmbito moral das pessoas, podendo ser citados o direito de resposta e a responsabilidade civil e penal.

Em 10 de junho de 2015, o Supremo Tribunal Federal decidiu, por unanimidade, que é inconstitucional exigir a autorização prévia para a produção e divulgação de biografias de pessoas públicas. Assim, julgou procedente a Ação Direta de Inconstitucionalidade n. 4.815, para dar interpretação conforme a Constituição aos arts. 20 e 21 do Código Civil, sem redução de texto. O entendimento que o Plenário do Supremo Tribunal Federal utilizou para decidir tal ação foi que a Constituição proíbe a censura de qualquer natureza e garante o acesso à informação e a liberdade de expressão. O texto constitucional também prevê a preservação da intimidade e imagem da pessoa e estabelece indenização e reparações em caso de abusos, mas sempre a posteriori.

Como já foi visto nesse trabalho, citando Paulo Gustavo Gonet Branco, o termo censura significa ação governamental, de ordem prévia, centrada sobre o conteúdo de uma mensagem. Portanto censura é somente a estatal, e com o devido respeito aos ilustres entendimentos contrários, não nos parece correto dizer "censura prévia particular". Logo, a não autorização de uma bibliografia não deve ser entendida como censura. 


\section{Conclusão}

Da pesquisa realizada podemos concluir que a censura que existiu em nosso país deixou sequelas e por conta disso provoca, até hoje, sentimentos de profunda rejeição. Ela destrói em nome da segurança, da moral, da família e dos bons costumes. Pela censura o Estado demonstra receio de que o povo não seja capaz de julgar por si só.

Importante que tenhamos claro que censura, juridicamente falando, deve ser entendida apenas a censura prévia feita pelo Estado, não sendo possível falar em censura prévia pessoal.

Após a Constituição da República Federativa do Brasil de 1988, a censura é tida como um verdadeiro ilícito constitucional, sendo ato injusto, arbitrário e discriminatório.

A liberdade de expressão, entendida como direito fundamental, tem principalmente um caráter de pretensão de que o Estado não exerça a censura. Portanto, o princípio geral que rege a matéria é a ampla liberdade de expressão, só se admitindo as restrições fundadas na própria Constituição. Assim, entre o embate do direito à liberdade de expressão e demais direitos tais como direito à proteção da criança e do adolescente, direito à vida privada, à intimidade, ao segredo e à imagem estes devem ser sopesados no caso concreto, não cabendo falar em censura em tais casos.

São Paulo, junho de 2016.

\section{Referências}

ALMEIDA, Maria das Graças Andrade Ataide de. Caça às bruxas: repressão e censura na interventoria Agamenon Magalhães (1937-1945). In: CARNEIRO, Maria Luiza Tucci (Org.). Minorias silenciadas. História da censura no Brasil. São Paulo: Edusp - Editora da Universidade de São Paulo, 2002.

AQUINO, Maria Aparecida de. Mortos sem sepultura. In: CARNEIRO, Maria Luiza Tucci (Org.). Minorias silenciadas. História da censura no Brasil. São Paulo: Edusp - Editora da Universidade de São Paulo, 2002.

BARROSO, Luís Roberto. Liberdade de expressão, censura e controle da programação de televisão na Constituição de 1988. Revista dos Tribunais, São Paulo, v. 90, n. 790, ago. 2001.

BRANCO, Paulo Gustavo Gonet. Direitos fundamentais em espécie. Capítulo 4. In: MENDES, Gilmar Ferreira; BRANCO, Paulo Gustavo Gonet. Curso de direito constitucional. 10. ed. São Paulo: Saraiva, 2015.

BRASIL. Collecção das leis do império do Brazil de 1827. Parte primeira: atos do poder legislativo. Rio de Janeiro: Typographia Nacional, 1878. 
BRASIL. Tribunal Federal de Recursos. A censura e a jurisprudência do TFR. Revista do Tribunal Federal de Recursos, Brasília, 1988. Separata, 2. ed.

CAMARGOS, Marcia Mascarenhas; SACCHETTA Vladimir. Procura-se Peter Pan... In: CARNEIRO, Maria Luiza Tucci (Org.). Minorias silenciadas: história da censura no Brasil. São Paulo: Edusp - Editora da Universidade de São Paulo, 2002.

CAMPANHOLE, Adriano; CAMPANHOLE, Hilton Lobo. Todas as constituições do Brasil. 2. ed., São Paulo: Atlas, 1976.

CARNEIRO, Maria Luiza Tucci. O mito da conspiração judaica e as utopias de uma comunidade. In: CARNEIRO, Maria Luiza Tucci (Org.). Minorias silenciadas: história da censura no Brasil. São Paulo: Edusp - Editora da Universidade de São Paulo, 2002.

CHINELLATO, Silmara Juny de Abreu. Biografias não autorizadas: liberdade de expressão, outros direitos da personalidade e Direito de Autor. Disponível em: <http://www.cidp.pt/publicacoes/ revistas/rjlb/2015/1/2015_01_0205_0238.pdf>. Acesso em: 10 mar. 2016.

FERREIRA, Aurélio Buarque de Holanda. Mini Aurélio. O dicionário da língua portuguesa. 8. ed. Curitiba: Editora Positivo, 2010.

. Novo dicionário da língua portuguesa. 1. ed., 15 impressão. Rio de Janeiro: Editora Nova Fronteira, 1975.

HOLANDA, Sérgio Buarque de. História do Brasil: estudos sociais. São Paulo: Companhia Editora Nacional, 1972. v. 1: Das origens à independência. p. 58. (Coleção Sérgio Buarque de Hollanda).

KUCINSKI, Bernardo. A primeira vítima: a autocensura durante o regime militar. In: CARNEIRO, Maria Luiza Tucci (Org.). Minorias silenciadas: história da censura no Brasil. São Paulo: Edusp Editora da Universidade de São Paulo, 2002.

MARTINS, Ana Luíza. Sob o signo da censura. In: CARNEIRO, Maria Luiza Tucci (Org.). Minorias silenciadas: história da censura no Brasil. São Paulo: Edusp - Editora da Universidade de São Paulo, 2002.

SILVA, Oscar José de Plácido e. Vocabulário jurídico. 15. ed., atualizadores Nagib Slaibi Filho e Geraldo Magela Alves. Rio de Janeiro: Forense, 1998.

SILVA, José Afonso da. Comentário contextual à constituição. 9. ed., atualizada até a Emenda Constitucional 83, de 5.8.2014. São Paulo: Malheiros, 2014.

SIMÕES, Inimá Ferreira. A censura cinematográfica no Brasil. In: CARNEIRO, Maria Luiza Tucci (Org.). Minorias silenciadas: história da censura no Brasil. São Paulo: Edusp - Editora da Universidade de São Paulo, 2002. 
